\title{
Factors Affecting Customer Intentions To Seek Islamic Microfinancing: Evidence From Indonesia
}

\author{
Amanda Riany Putri \\ Faculty of Economics and Business \\ Universitas Indonesia \\ Depok, Indonesia \\ amandarp96@gmail.com
}

\author{
Irfani Fithria \\ Faculty of Economics and Business \\ Universitas Indonesia \\ Depok, Indonesia \\ irfanifithria@gmail.com
}

\author{
Rahmatina Awaliah Kasri \\ Faculty of Economics and Business \\ Universitas Indonesia \\ Depok, Indonesia \\ unirahma@gmail.com
}

\begin{abstract}
Abstract-Micro, small, and medium-sized enterprises (MSMEs) contribute significantly to global GDP and employment, especially in developing economies like Indonesia. Unfortunately, MSMEs have little access to formal sources of external finance. The rise of Islamic microfinance potentially can overcome this constraint. This study analyzes five factors that determine MSMEs' intention to seek Islamic microfinance as a source of business financing. Drawing upon the Theory of Planned Behavior, we sample 160 customers from four branches of two Islamic microfinance institutions in Indonesia. Using partial least squares structural equation modeling, we measured the influences of five variables on their microfinancing intentions: attitude, subjective norms, perceived behavioral control, pricing, and religiosity. Results show that attitude, subjective norms, perceived behavioral control, and religiosity influence intention to seek Islamic microfinance. Pricing had a negative effect. These results help Islamic financial institutions to improve attract clients and design strategies to expand markets.
\end{abstract}

Keywords- Islamic microfinance, theory of planned behavior, religious factor, pricing factor, intention to use, MSMEs, Islamic microfinance institutions

\section{INTRODUCTION}

Micro, small, and medium-sized enterprises (MSMEs) contribute significantly to global GDP and employment [1]. During the past five years, their contribution to Indonesia's GDP has grown from $57.84 \%$ to $60.34 \%$ [2].

However, MSMEs globally and in Indonesia have limited access to capital [3] threatening their viability. Few banks serve remote areas of Indonesia, and MSMEs might not fulfill conventional lending requirements. About $60 \%-70 \%$ of MSMEs in Indonesia have been unable to access financing or bank credit [4]

Sharia-compliant banking offers a solution to these problems and is growing worldwide because its practices accord with Islamic principles. As a subset of Shariacompliant banking, microfinance institutions have succeeded in Muslim-majority countries such as Bangladesh, Pakistan, and Turkey [5] and they have attained prominence in Indonesia (Table 1.1).

TABLE 1.1. Number OF ISLAMIC MiCROFINANCE INSTITUTION IN INDONESIA

\begin{tabular}{|l|l|l|}
\hline Type of Institution & \multicolumn{1}{|c|}{ Year } & \multicolumn{1}{c|}{ Amount } \\
\hline BPRS & 2017 & 441 units \\
\hline BMT \& sharia cooperative & 2016 & 2.253 units \\
\hline a. Source: Statistics of Sharia Banking OJK\&Ministry of
\end{tabular}

Source: Statistics of Sharia Banking OJK\&Ministry of Cooperatives and SMEs

of Indonesians who seek Islamic financing. To realize that potential, Indonesia's microfinance institutions must understand the factors that attract customers. Drawing upon the Theory of Planned Behavior (TPB), we empirically investigate five factors that influence intentions to use Islamic microfinance: attitude, subjective norms, perceived behavioral control, pricing, and religiosity.

Previous studies focus on intentions to use Shariacompliant financial products generally-e.g., personal loans, savings, and home financing. Few examine Islamic financial products within the scope of microfinance. None uses the TPB to explain what draws customers to seek Shariacompliant microfinance

\section{LITERATURE REVIEW}

\subsection{Concept of Financing in Islam}

Indonesian law defines Sharia banking as the provision of financial products and services that comply with Sharia law. Those include:

a) profit-sharing transactions such as mudaraba (trust contracts) and musharaka (partnership);

b) lease transactions such as ijara (rent to buy) or lease purchase such as ijarah muntahiya bittamlik (profit and principal financing);

c) sale and purchase transactions such as accounts receivable like murabahah(sale), salam(the subject 
can be anything), and istishna (the subject is manufacture);

d) lending and borrowing such as qardh (loan/debt); and

e) service lease transactions such as ijarah for multilateral transactions, based on agreements between a Sharia Bank and/or UUS and another party requiring the party financed and/or granted a fund facility to refund the funds after a stipulated period in exchange for ujrah without rewards, or profit sharing.

Islam supports transfer of wealth that assists the needy [6]. Islamic financing has two goals: channeling resources from surplus to deficit units and meeting human needs whereby Muslims improve their welfare (Kahf and Khan, 1992). Debt must be based on genuine need, and Islam enjoins its followers to have no debt [7].

\subsection{Conceptual Framework and Hypothesis Development}

TPB holds that three factors influence intention: attitude, subjective norms, and perceived behavioral controls. This theory is an update from the Theory of Reasoned Action by entering perceived behavioral control to produce the framework in Figure 2.1

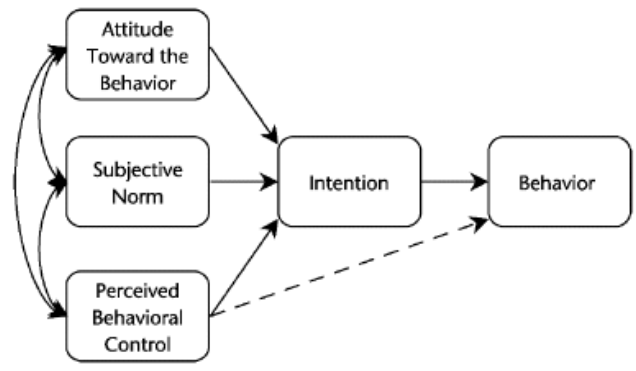

Source: Ajzen, 2005

Fig 2.1. Theory of planned behavior

\subsubsection{Intention}

Country governance is an essential facet in Islamic bank According to Ramdhani [8], intention is a personal determination to perform an act. Intention indicates the extent to which someone wants to engage in a behavior [9]. TPB measures three influences on intention: attitude, subjective norms, and perceived behavioral control. Someone who intends to engage in a behavior responds to those influences; whoever does not respond to them is less likely to engage in the behavior [10].

\subsubsection{Attitude}

Attitude is our personal assessment of whether consequences of our behavior will be positive or negative. Amin et al. [6] find that attitude greatly affects intentions to seek personal financing through Islamic banks in Malaysia. Other studies confirm that finding attitude also has a contribution to the intention of financing KPR sharia in Malaysia [11].

\section{We propose Hypothesis 1:}

H1: Attitude has a positive influence on the intention to seek Islamic microfinance financing.

\subsubsection{Subjective Norms}

Ramdhani [8] defines subjective norms as our perception of how people important to us will regard our behavior. Ali, Ali, and Hong [12] find that subjective norms influence the intention to seek Islamic personal financing in Pakistan. Other studies find that subjective norms enhance the intention to seek Sharia financing for Malaysia [11]

We propose Hypothesis 2:

$\mathrm{H} 2$ : Subjective norms has a positive influence on the intention to seek Islamic microfinance

\subsubsection{Perceived Behavioral Control}

Perceived behavioral control (PBC) is our perception of the effort needed to affect a behavior [9] and how strongly we believe we control whether we do so. PBC is determined by our beliefs about factors that may facilitate or hinder an action. Jaffar and Musa (2015) call it the strongest predictor of whether MSME entrepreneurs seek Sharia financing. Their finding is supported by studies that establish a relation between $\mathrm{PBC}$ and the intention to finance homes through Sharia banks $[6,13]$

We propose Hypothesis 3:

H3: PBC has a positive influence on the intention to seek Islamic microfinance

\subsubsection{Pricing}

Generally, price refers to amounts Islamic finance institutions charge for products and services In setting an appropriate price, they balance their profits and customers' benefits and compete with non-Islamic institutions for customers. Hududin and Rahman (2011) find that sizably negative prices diminish Muslims' intention to seek personal financing with Islamic banks. Ali et al. [7] find that pricing exerts a negative and significant influence on use of Islamic financing.

We propose Hypothesis 4:

H4: Price has a negative influence on the intention to seek Islamic microfinance

\subsubsection{Religiosity}

Generally, price refers to amounts Islamic finance institutions charge for products and services In setting an appropriate price

Johnson, et al. [14] define religiosity as a commitment to religious teachings that is reflected in daily behavior. Reni and Ahmad (2016) find that religion has a significant influence influences choosing Islamic banking in Indonesia. Alam et al (2015) find that same result for Malaysia.
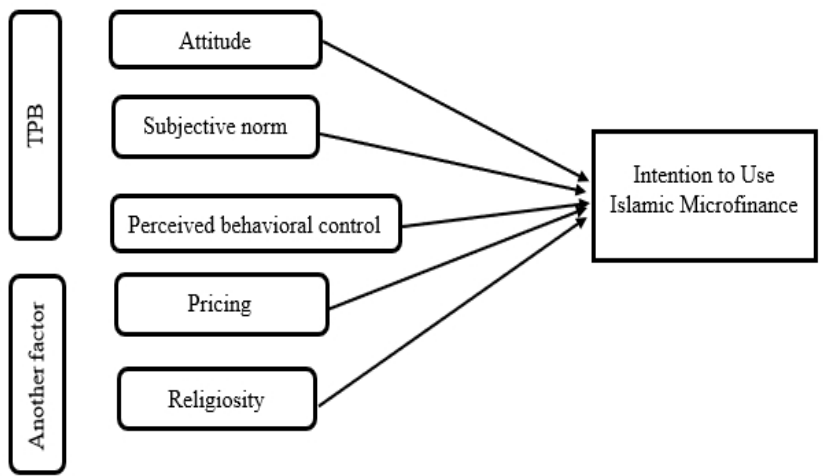

Fig 2.2. Framework of research model 


\section{METHOD}

We obtained primary data from survey questionnaires distributed to 160 microfinance customers of Islamic institutions in Jakarta, Bogor, Depok, and Tangerang. The institutions are Baitul Maal wa Tamwil (two branches) and Bank Pembiayaan Rakyat Syariah (two branches).

We employed nonprobability and convenience sampling. Convenience sampling determines respondents by chancei.e., anyone who encounters the researcher can be a suitable data source [15].

To analyze factors that influence intention to seek Islamic microfinance we used partial least squares structural equation modeling (PLS-SEM). Used to test new theories [16]. SEM indicates whether data support a model and analyzes multi-variables better than ordinary multiregression, especially data that do not meet normality conditions. PLS-SEM is excellent for confirmation and exploration research and does not require an excessive number of samples. PLS-SEM is suitable for use to research models that have not been ascertained [17]. SEM-PLS analysis requires the researcher to analyze a measurement model and a structural model.

\section{RESULT AND DISCUSSION}

The questionnaire was divided into two sections: demographic data and independent variables. Table 4.1 profiles the 160 respondents:

\section{Analysis of SEM-PLS}

We used Smart PLS 3.0 for the PLS analysis of the measurement model and the structural model.

\section{Measurement Model Analysis}

Measurement analysis determines the model's validity and reliability and each variable's significance. To analyze the measurement model we calculated the loading factor (AVE method), composite reliability, Cronbach's alpha, cross-loading, and T-values. Convergent validity is evident from factor loading (AVE) values > 0.5 [18]. Discriminant validity is evident from cross-loading; a value is sound if it correlates strongly to the latent variable. Reliability is evident in composite reliability values $>0.7$ and Cronbach's alpha $>0.6$ [19]. The significance of the measurement model is evident if T-values > 1.645 (one tailed).

Testing confirmed all measurement indicators. Models and indicators are valid and reliable, and each variable is statistically significant.

\subsection{Analysis of Structural Models}

The structural model shows the relation between the independent and dependent variables [20] to assess the structural model we calculate $\mathrm{R}^{2}$ and communality $\left(\mathrm{h}^{2}\right)$ to find goodness of fit (GoF) and test hypotheses.

Significance values of structural models are in Table 4.4. Not all independent variables significantly influence the dependent variable. Variables that bolster intention to seek Islamic microfinance at $95 \%$ confidence are attitude, subjective norms, behavior control, and religiosity.
TABLE 4.1. DEMOGRAPHIC PROFILE RESPONDENTS

\begin{tabular}{|c|c|c|c|}
\hline No & Demographic Items & Frequency & Percentile \\
\hline \multirow[t]{3}{*}{1} & Gender & & \\
\hline & Male & 100 & $62.5 \%$ \\
\hline & Female & 60 & $37.5 \%$ \\
\hline \multirow[t]{7}{*}{2} & Age & & \\
\hline & $<25$ & 1 & $0.63 \%$ \\
\hline & $25-34$ & 29 & $18.13 \%$ \\
\hline & $35-44$ & 74 & $46.25 \%$ \\
\hline & $45-54$ & 38 & $23.75 \%$ \\
\hline & $55-64$ & 16 & $10.00 \%$ \\
\hline & $>64$ & 2 & $1.25 \%$ \\
\hline \multirow[t]{4}{*}{3} & Marital Status & & \\
\hline & Married & 156 & $97.50 \%$ \\
\hline & Single & 1 & $0.63 \%$ \\
\hline & Widower/widow & 3 & $1.88 \%$ \\
\hline \multirow[t]{7}{*}{4} & Level of Education & & \\
\hline & Not in school & 1 & $0.63 \%$ \\
\hline & Elementary school & 18 & $11.25 \%$ \\
\hline & Junior high school & 39 & $24.38 \%$ \\
\hline & Senior high school & 83 & $51.88 \%$ \\
\hline & Diploma & 11 & $6.88 \%$ \\
\hline & Bachelor & 8 & $5 \%$ \\
\hline \multirow[t]{3}{*}{5} & Institution & & \\
\hline & BMT & 61 & $61.88 \%$ \\
\hline & BPRS & 99 & $38.13 \%$ \\
\hline
\end{tabular}

TABLE 4.2. OUtPut MEASUREMENT MODEL INTENTION TO SEEK ISLAMIC MICROFINANCE

\begin{tabular}{|l|l|l|l|l|l|}
\hline \multicolumn{1}{|c|}{ 6 } & AVE & $\begin{array}{l}\text { Composite } \\
\text { Reliability }\end{array}$ & $\begin{array}{c}\text { Cronbach' } \\
\text { S Alpha }\end{array}$ & $\begin{array}{c}\text { Cross- } \\
\text { loading }\end{array}$ & T-Values \\
\hline ATT & 0.753 & 0.938 & 0.917 & $\begin{array}{l}\text { The largest } \\
\text { in the ATT } \\
\text { variable }\end{array}$ & Significant \\
\hline SN & 0.618 & 0.889 & 0.849 & $\begin{array}{l}\text { The largest } \\
\text { in the SN } \\
\text { variable }\end{array}$ & Significant \\
\hline PBC & 0.743 & 0.920 & 0.885 & $\begin{array}{l}\text { The largest } \\
\text { in the PCB } \\
\text { variable }\end{array}$ & Significant \\
\hline R & 0.738 & 0.932 & 0.910 & $\begin{array}{l}\text { The largest } \\
\text { in the R } \\
\text { variable }\end{array}$ & Significant \\
\hline P & 0.661 & 0.906 & 0.884 & $\begin{array}{l}\text { The largest } \\
\text { in the P } \\
\text { variable }\end{array}$ & Significant \\
\hline INT & 0.727 & 0.929 & 0.902 & $\begin{array}{l}\text { The largest } \\
\text { in the INT } \\
\text { variable }\end{array}$ & Significant \\
\hline
\end{tabular}

We conclude from the values of $\mathrm{R}^{2}$ and $\mathrm{h}^{2}$ that the $\mathrm{GoF}=$ 0.7226. $\mathrm{GoF}=0.10$ qualifies as small, $\mathrm{GoF}=0.25$ medium, and $\mathrm{GoF}=0.36$ large (Latan \& Ghozali, 2012). GoF scores in our model are high-category.

TABLE 4.3. GOODNESS OF FIT ANALYSIS

\begin{tabular}{|l|c|c|}
\hline Variable & R2 & Communality \\
\hline ATT & - & 0.753 \\
\hline SN & - & 0.618 \\
\hline PBC & - & 0.743 \\
\hline R & - & 0.738 \\
\hline P & - & 0.661 \\
\hline INT & 0.739 & 0.727 \\
\hline Average & $\mathbf{0 . 7 3 9}$ & $\mathbf{0 . 7 0 6 6 6 7}$ \\
\hline
\end{tabular}


TABLE 4.4. HYPOTHESIS TEST ANALYSIS

\begin{tabular}{|l|c|c|l|}
\hline \multicolumn{1}{|c|}{ Variable } & $\begin{array}{c}\text { Original } \\
\text { Sample }\end{array}$ & T-Statistics & \multicolumn{1}{|c|}{ Information } \\
\hline ATT ke INT & 0.274 & 3.185 & Positive \& Significant \\
\hline SN ke INT & 0.130 & 2.408 & Positive \& Significant \\
\hline PBC ke INT & 0.454 & 5.266 & Positive \& Significant \\
\hline R ke INT & 0.181 & 4.213 & Positive \& Signifikan \\
\hline P ke INT & -0.107 & 1.539 & $\begin{array}{l}\text { Negative \& Not } \\
\text { Significant }\end{array}$ \\
\hline
\end{tabular}

In Table 4.4, the attitude variable (ATT) has a correlation of 0.274 to intention (INT) (t-statistic > 1.645). $\mathrm{H} 1$ is confirmed. Attitude positively and significantly affects intention to seek Islamic microfinance. These results accord with Ali, Raza, and Chin-hong (2015) and Amin et al [6].

In Table 4.4, the subjective norm variable (SN) has a correlation of 0.130 to intention (INT) (t-statistic > 1.645) $\mathrm{H} 2$ is confirmed. Approval of people who are important to the customer bolsters the intention to seek Islamic microfinance. This finding supports M. Ali et al. [12] and Amin et al. [6]

In Table 4.4, the correlation for PBC has a correlation of 0.454 to intention (INT) (t-statistic > 1.645). $\mathrm{H} 3$ is confirmed. PBC positively and significantly affects intention to seek Islamic microfinance. This finding accords with Ali et al. [12] and Nature et al. (2012). Customers in this study feel they have the ability to seek Islamic microfinance and control over doing so.

In Table 4.4, the coefficient of price $(\mathrm{P})$ is the smallest among all variables $(-0.107)$, negative, and not statistically significant (t-statistic < 1.654). H4 is confirmed. This finding seems counterintuitive. One explanation is that MSMEs have limited access to external financing and will take available opportunities despite a higher price. Another explanation is that Muslim customers are concerned with securing Sharia-compliant financing irrespective of price. That likelihood is confirmed by Dusuki and Abdullah (2006), Reni and Ahmad (2016), M. S. I. Ali \& Athambawa [22], and our findings concerning Hypothesis 4

In Table 4.4, the religiosity variable (R) has a correlation of 0.181 to intention (INT) (t-statistic > 1.645). Customers' daily commitment to Islam faith and its precepts positively and significantly influences intentions to seek Islamic microfinance. H5 is confirmed. This result is supported by Ibrahim, Fisol, and Hajj-Othman [21], Ali et al [7], Nature et al (2012), and Amin et al [6].

\section{CONCLUSION AND IMPLICATION}

Data and analysis confirm that attitude, SNs, PBC, and religiosity bolster customers' intentions to seek Islamic microfinancing. Intentions to seek Islamic microfinance are stronger when customers respond affirmatively to the idea, when their social network endorses it, when they feel capable of engaging in Islamic microfinance, and when they observe their faith in daily life.

Results also confirm that customers are not influenced by the cost of Islamic microfinance products and services.

We examined only four branches of two Islamic microfinance institutions in Jakarta, Bogor, Depok, and Tangerang. More geographically dispersed research involving more banks and branches could expand our findings and their generalizability. Further research also should include additional variables.

\section{REFERENCES}

[1] EdinburghGroup. (2014). Growing the global economy through SMEs. The Edinburgh Group. Retrieved from http://www.edinburghgroup.org/media/2776/edinburgh_group_research_growing_the_glo bal_economy_through_smes.pdf

[2] Kementrian Perindustrian Republik Indonesia. (2018). Kontribusi UMKM Naik http://www.kemenperin.go.id/artikel/14200/KontribusiUMKM-Naik

[3] Christopher, I. F. (2010). Impact of Microfinance on Small and Medium-Sized Enterprises in Nigeria. In 7th International Conference on Innovation \& Management (pp. 1864-1871).

[4] Sarwono, H. A. (2015). Profil Bisnis Usaha Mikro, Kecil Dan Menengah (UMKM). Bank Indonesia dan LPPI.

[5] Rokhman, W. (2013). The Effect of Islamic Microfinance on Poverty Alleviation: Study in Indonesia. Journal of Economics and Business, XI(2), 21-31.

[6] Ali, M., Raza, S. A., \& Chin-hong, P. (2015a). Factors affecting intention to use Islamic personal financing in Pakistan: Evidence from the modified TRA model. Munich Personal RePEc Archive Factors.

[7] Amin, H., Rahim, A., Rahman, A., Sondoh, S. L., Magdalene, A., \& Hwa, C. (2011). Determinants of customers ' intention to use Islamic personal financing The case of Malaysian Islamic banks. Journal of Islamic Accounting and Business Research, 2(1), 22-42. https://doi.org/10.1108/17590811111129490.

[8] Ramdhani, N. (2011). Penyusunan Alat Pengukur Berbasis Theory of Planned Behavior. Buletin Psikologi, 19(2), 55-69. https://doi.org/10.22146/bpsi.11557

[9] Azjen, I. (2005). Attitudes, Personality \&amp; Behaviour. Retrieved from https://psicoexperimental.files.wordpress.com/2011/03/ajzeni2005-attitudes-personality-and-behaviour-2nd-ed-open-universitypress.pdf

[10] Yuliana. (2004). Pengaruh Sikap terhadap Pindah Kerja, Norma Subjektif, Perceived Behavioral Control terhadap Intensi Pindah Kerja pada Pekerja Teknologi Informasi. Phronesis: Jurnal Ilmiah Psikologi Terapan, 6 (11), 1-18.

[11] Amin, H., Amin, H., Rahim, A., Rahman, A., \& Abdul Razak, D. (2014). Consumer acceptance of islamic home financing. International Journal of Housing Markets and Analysis, 7(3), 307332. https://doi.org/10.1108/IJHMA-12-2012-0063.

[12] Ali, M., Raza, S. A., \& Chin-hong, P. (2015b). Islamic home financing in Pakistan: A SEM based approach using modified TPB model. Munich Personal RePEc Archive Factors, (67877).

[13] Alam, S. S., Janor, H., Zanariah, Wel, C. A. C., \& Ahsan, M. N. (2012). Is Religiosity an important factor in influencing the intention to undertake Islamic home financing in Klang Valley? World Applied Sciences Journal, 19(7), 1030-1041. https://doi.org/10.5829/idosi.wasj.2012.19.07.392.

[14] Johnson, B.R., Jang, S.J., Larson, D.B. \& Li, S.D. (2001). Does Adolescent Religious Commitment Matter? A Reexamination of the Effects of Religiosity on Delinquency. Journal of Research in Crime and Delinquency, Vol. 38, No. 1, pp. 22- 43.

[15] Sugiyono. (2017). Metode Penelitian Kuantitatif, Kualitatif, dan R\&D. Bandung: Alfabeta

[16] Alavifar, A., Karimimalayer, M., \& Anuar, M. K. (2012). Structural equation modeling VS multiple regression. Engineering Science and Technology: An International Journal (ESTIJ), 2(2), 326-329. Retrieved http://www.estij.org/papers/vol2no22012/25vol2no2.pdf.

[17] Geven, D., Straub, D. W., \& Bodreau, M. C. (2000). STRUCTURAL EQUATION MODELING AND REGRESSION: GUIDELINES FOR RESEARCH PRACTICE. Communications of the Association for Information Systems, 4.

[18] Hair, J. F., Black, W. C., Babin, B. J., \& Anderson, R. E. (2010). Multivariate data analysis (7th ed.). Englewood Cliffs: Prentice Hall.

[19] Malhotra, N. K. 2010. Marketing Research: An Applied Orientation. Pearson International Education: Limited.

[20] Ghozali, Prof. Dr. H. Imam. (2016). Aplikasi Analisis Multivariete dengan Program IBM SPSS 23. Semarang: Badan Penerbit Universitas Diponegoro.

[21] Ibrahim, M. A., Fisol, W. N. M., \& Haji-Othman, Y. (2017). Customer Intention on Islamic Home Financing Products: An Application of Theory of Planned Behavior (TPB). Mediterranean 
Journal of Social Sciences, 8(2), 77-86. https://doi.org/10.5901/mjss.2017.v8n2p77.

[22] Ali, M. S. I., \& Athambawa, S. (2008). Determinants of customers ' intention to use Islamic financing services- The
Case of Islamic Bank in Sri Lanka. In Proceedings of the Second ARC, FMC, SEUSL (pp. 91-99) 